\title{
Improvement of Glucose Tolerance by Food Factors Having Glucagon-Like Peptide-1 Releasing Activity
}

\author{
Tohru Hira ${ }^{1,2,3, *}$, Aphichat Trakooncharoenvit ${ }^{2}$, Hayate Taguchi ${ }^{3}$ and Hiroshi Hara ${ }^{4}$ \\ 1 Research Faculty of Agriculture, Hokkaido University, Sapporo 060-8589, Japan \\ 2 Graduate School of Agriculture, Hokkaido University, Sapporo 060-8589, Japan; \\ trakooncharoenvit.aphichat.p0@elms.hokudai.ac.jp \\ 3 School of Agriculture, Hokkaido University, Sapporo 060-8589, Japan; hayate-taguchi@eis.hokudai.ac.jp \\ 4 Department of Food Science and Human Nutrition, Fuji Women's University, Ishikari-shi 061-320, Japan; \\ hara@fujijoshi.ac.jp \\ * Correspondence: hira@chem.agr.hokudai.ac.jp
}

Citation: Hira, T.; Trakooncharoenvit, A.; Taguchi, H.; Hara, H. Improvement of Glucose Tolerance by Food Factors Having Glucagon-Like Peptide-1 Releasing Activity. Int. J. Mol. Sci. 2021, 22, 6623. https://doi.org/ $10.3390 /$ ijms 22126623

Academic Editor: Kazumi Yagasaki

Received: 25 May 2021

Accepted: 17 June 2021

Published: 21 June 2021

Publisher's Note: MDPI stays neutral with regard to jurisdictional claims in published maps and institutional affiliations.

Copyright: (C) 2021 by the authors. Licensee MDPI, Basel, Switzerland. This article is an open access article distributed under the terms and conditions of the Creative Commons Attribution (CC BY) license (https:// creativecommons.org/licenses/by/ $4.0 /)$.

\begin{abstract}
Glucagon-like peptide-1 (GLP-1) is a gastrointestinal hormone released from enteroendocrine L cells in response to meal ingestion. GLP-1 receptor agonists and GLP-1 enhancers have been clinically employed to treat diabetes owing to their glucose-dependent insulin-releasing activity. The release of GLP-1 is primarily stimulated by macronutrients such as glucose and fatty acids, which are nutritionally indispensable; however, excessive intake of sugar and fat is responsible for the development of obesity and diabetes. Therefore, GLP-1 releasing food factors, such as dietary peptides and non-nutrients, are deemed desirable for improving glucose tolerance. Human and animal studies have revealed that dietary proteins/peptides have a potent effect on stimulating GLP-1 secretion. Studies in enteroendocrine cell models have shown that dietary peptides, amino acids, and phytochemicals, such as quercetin, can directly stimulate GLP-1 secretion. In our animal experiments, these food factors improved glucose metabolism and increased GLP-1 secretion. Furthermore, some dietary peptides not only stimulated GLP-1 secretion but also reduced plasma peptidase activity, which is responsible for GLP-1 inactivation. Herein, we review the relationship between GLP-1 and food factors, especially dietary peptides and flavonoids. Accordingly, utilization of food factors with GLP-1-releasing/enhancing activity is a promising strategy for preventing and treating obesity and diabetes.
\end{abstract}

Keywords: GLP-1; dietary peptides; flavonoids

\section{Introduction}

Glucagon-like peptide-1 (GLP-1) [1] is a gastrointestinal hormone produced in enteroendocrine cells, termed L cells or GLP-1-producing cells. GLP-1 is released in response to meal ingestion (generally within $15-30 \mathrm{~min}$ ) and enhances insulin secretion from pancreatic beta-cells, which contributes to normalizing (attenuating) the postprandial glycemic response. Due to its insulinotropic effects, GLP-1 is also called the "incretin" hormone. Another gastrointestinal hormone, glucose-dependent insulinotropic polypeptide (GIP), also functions as an incretin. GIP is released from other enteroendocrine cells, termed as $\mathrm{K}$ cells, in response to nutrient ingestion. GIP is produced in the proximal small intestine, and released GIP stimulates GLP-1 secretion. This evidence highlights the role of "a proximal-to-distal GIP-GLP-1 axis" in postprandial incretin responses [1].

GLP-1 has multiple actions, including promoting beta-cell growth, protecting betacell apoptosis, and reducing glucagon secretion from alpha-cells in the pancreas. In addition, GLP-1 demonstrates several extra-pancreatic actions, such as suppressing gastric emptying and food intake [1]. As GLP-1 and GIP are immediately degraded by a peptidase, i.e., dipeptidyl peptidase-4 (DPP-4), in the plasma and tissues, their half-life is estimated to be $1-2 \mathrm{~min}$ and $7 \mathrm{~min}$, respectively [2-4]. 
More importantly, owing to its incretin action, GLP-1 receptor agonists (GLP-1 RAs) developed from a DPP-4 resistant GLP-1 analog (exenatide or exendin-4 identified from the saliva of a venomous lizard) are currently utilized in type-2 diabetes therapy [5]. Most GLP1RAs need to be administered as injections (daily or weekly); however, an orally available GLP-1RA has been recently developed. Oral semaglutide is co-formulated with sodium $\mathrm{N}$-(8-(2- hydroxybenzoyl) amino) caprylate (SNAC) and is absorbed through the stomach mucosa to exert its biological effect as a GLP-1RA [6]. Furthermore, DPP-4 inhibitors [7], such as sitagliptin and vildagliptin, are employed to treat type-2 diabetes as orally effective incretin (both GLP-1 and GIP) enhancers. GLP-1 RAs, but not DPP-4 inhibitors, reportedly promote a reduction in calorie intake and body weight due to the appetite-suppressing effect of GLP-1 receptor activation [5]. Accordingly, GLP-RAs and DPP-4 inhibitors are a well-established class of glucose-lowering agents for treating type 2 diabetes.

The efficacy of GLP-1 RAs and DPP-4 inhibitors in normalizing glucose metabolism indicates the possibility of GLP-1 and GIP deficiencies under conditions of obesity and/or glucose intolerance. Some early studies reported that GLP-1 secretory responses to oral glucose load or meal ingestion were diminished in individuals presenting with obesity, glucose intolerance, or diabetes when compared with those observed in healthy subjects $[8,9]$.

However, results from subsequent human and animal studies were not consistent in terms of impaired GLP-1 secretion under these conditions [10-15]. In our animal studies [16-19], GLP-1 secretory responses to meal ingestion were consistently higher in diet-induced obese rats than in control rats. An enhanced GLP-1 response during the development of glucose tolerance and obesity could afford a protective effect against glucose intolerance [20]. In addition, GLP-1RAs are clinically effective in normalizing glycemia in patients with diabetes and obesity.

These findings indicate that increasing endogenous GLP-1 secretion by using orally administered drugs or food factors could be a novel and promising strategy for preventing glucose intolerance or improving glucose tolerance. Thus, in the present review, we focus on the effects of dietary factors on GLP-1 stimulation.

\section{Dietary Factors and GLP-1}

\subsection{Macronutrients}

The ingestion of a meal plays a major role in stimulating GLP-1 secretion. GLP-1producing enteroendocrine cells (L cells) are scattered throughout the epithelium of the small and large intestines. Although GLP-1-producing cells are primarily located in the distal small intestine and the large intestine (cecum and colon), they are also present in the jejunum [21,22]. Therefore, GLP-1-producing cells in the small intestine are likely responsible for the acute postprandial GLP-1 responses induced by luminal nutrients [23]. In contrast, GLP-1-producing cells in the large intestine are possibly involved in prolonged or basal GLP-1 secretion promoted by the luminal content in the large intestine, such as short-chain fatty acids (SCFAs) produced by gastrointestinal microbiota [23].

Among macronutrients, glucose is the best-known molecule responsible for stimulating GLP-1 secretion [23], with a stimulatory mechanism similar to glucose-induced insulin secretion in pancreatic beta-cells. Glucose is taken up into GLP-1-producing cells, as well as into absorptive epithelial cells, through the sodium-dependent glucose transporter-1 (SGLT-1). In GLP-1-producing cells, glucose is metabolized to produce ATP, which induces the closure of the ATP-sensitive potassium channel ( $\mathrm{K}_{\text {ATP }}$ channel). $\mathrm{K}_{\text {ATP }}$ channel closure leads to the opening of a depolarization-dependent calcium channel, resulting in intracellular calcium mobilization and subsequent GLP-1 exocytosis. Although the molecular mechanisms remain poorly understood, fructose is also a potent GLP-1 stimulator [24]. Additionally, the involvement of the sweet taste receptor (G-protein-coupled receptor (GPCR) heterodimer TAS1R2 and TAS1R3) has been proposed for sensing glucose and sweeteners [25-27].

Long-chain fatty acids liberated from dietary triacylglycerol potently stimulate GLP-1 secretion through GPCRs such as FFRA1 (GPR40) and FFAR4 (GPR120). In terms of 
the chain-length dependency, fatty acids with more than 12 chains demonstrate a GLP-1 releasing effect [28]. Previous human studies demonstrated an olive oil-rich meal induced a higher GLP-1 response than a butter-rich meal [29,30], suggesting that unsaturated fatty acids are more effective stimulators of GLP-1 secretion than saturated fatty acids. However, structure-activity relationships regarding the degree of unsaturation and positions of the double bond remain unclear. 2-Oleoil glycerol (2-OG) is a specific monoacylglycerol known to stimulate GLP-1 secretion through GPR119, which is also activated by the fatty acid derivative oleoylethanolamide (OEA) [31,32].

Protein-, peptide- and amino acid-induced GLP-1 secretions are separately described below.

\subsection{Micronutrients}

The direct effects of vitamins and minerals on gastrointestinal hormone secretion, including GLP-1 secretion, remain unknown. One possible mineral that stimulates GLP-1 secretion is calcium, as the extracellular calcium-sensing receptor (CaSR) is expressed and functions in GLP-1-producing cells as a sensor for specific amino acids and peptides [33,34]. However, whether dietary or luminal calcium alone induces GLP-1 secretion needs to be clarified.

\subsection{Other Food Factors}

In the large intestine, fermentable dietary fibers are a major source of SCFAs, such as acetate, propionate, and butyrate. The stimulatory effects of chronic dietary fiber ingestion on GLP-1 secretion have been reported in various animal and human studies, as summarized in a previous review [35]. Previous reports [36,37] have demonstrated that acetate and propionate stimulate GLP-1 secretion through the free fatty acid receptor 2 (FFAR2, also called GPR43) and free fatty acid receptor 3 (FFAR3, also called GPR41). Another study revealed that SCFAs are intracellularly metabolized to produce energy, subsequently triggering GLP-1 secretion [38].

Continuous feeding with resistant maltodextrin (RMD) increased plasma GLP-1 concentrations, accompanied by increased SCFA production in normal rats and high fat/high sucrose diet-fed rats $[17,39]$. In a murine enteroendocrine GLP-1-producing cell line (GLUTag cells), RMD exposure for 60 min increased GLP-1 release into the supernatant, and a direct infusion of RMD into the small intestine of anesthetized rats acutely increased portal plasma GLP-1 concentrations [39]. As these experimental models do not include gut microbiota, the results suggest a direct effect of RMD molecules on GLP-1 secretion in GLP-1-producing cells.

D-allulose, a non-metabolizable sugar, exerts potent GLP-1 release in rat and mouse models $[40,41]$. Oral administration of D-allulose restricted overeating and hyperglycemia by increasing GLP-1 secretion in mice. Interestingly, D-allulose induced GLP-1 secretion but not affected GIP secretion. Most macronutrients stimulate both GLP-1 and GIP secretion, and GIP promotes adiposity [4], an undesirable action during obesity. The GLP-1-specific action of D-allulose is an attractive property for the prevention and amelioration of obesity and diabetes. The effects of RMD and D-allulose on GLP-1 secretion in humans and the mechanism underlying RMD and D-allulose-induced GLP-1 secretion need to be comprehensively investigated in future studies.

The effects of phytochemicals on GLP-1 are separately described below.

\section{Dietary Proteins/Peptides/Amino Acids and GLP-1}

\subsection{Proteins}

Recently, dietary proteins and peptides have been recognized as potent GLP-1 secretagogues [42], as reported in several animal and human studies. Meals composed of higher amounts of protein stimulate GLP-1 secretion substantially [43-45] and are associated with reduced glycemia and/or enhanced satiety. However, this may not always be observed, as it is difficult to control the experimental design under iso-caloric conditions. In order to adjust for identical energy in test meals (isocaloric condition), on increasing 
the protein proportion, the carbohydrate and/or fat proportion needs to be decreased, which are also potent GLP-1 stimulators. Furthermore, it is difficult to ingest adequate amounts (e.g., $75 \mathrm{~g}$ ) of pure protein when compared with $75 \mathrm{~g}$ glucose (typical dose used in human glucose tolerance tests), as most dietary proteins are insoluble in water and poorly palatable. Therefore, human studies directly comparing the effects of pure macronutrients are limited [46].

On comparing the effects of isocaloric ( $8 \mathrm{kcal} / \mathrm{kg}$ body weight) glucose, fat (olive oil), and protein (whey protein and egg protein mixture) on GLP-1 secretion in nondiabetic subjects, fat reportedly induced the highest increment in GLP-1 secretion [46]. As described above, whey protein is predominantly used in human studies and exerts a GLP-1 stimulating action, followed by insulinotropic and glucose-lowering effects. Accordingly, whey protein is now employed as a positive control to stimulate GLP-1 secretion.

Some studies have demonstrated the effects of intact proteins on GLP-1 secretion in enteroendocrine cell models (STC-1 and pGIP/Neo STC-1 cells). On examining various intact proteins, casein, codfish, egg, and wheat revealed potent effects on GLP-1 secretion from STC-1 cells [47]. Among whey protein components ( $\alpha$-lactalbumin and $\beta$-lactoglobulin), $\alpha$-lactalbumin is potently stimulated [48], and among casein subunits ( $\alpha-, \beta$, k-casein), $\alpha$ - and $\beta$-casein stimulated GLP-1 secretion from pGIP/Neo STC-1 cells [49]. In GLUTag cells, the micellar casein concentrate, but not sodium caseinate mixed with whey protein isolate, induced GLP-1 secretion [50].

As cell lines are incapable of digesting these proteins, these findings indicate that specific polypeptide structures, not only peptides and free amino acids, are involved in the stimulatory effect on GLP-1 secretion.

\subsection{Peptides}

As dietary proteins are digested in the stomach and intestinal lumen, digestive products such as peptides and amino acids stimulate the GLP-1 producing cells in the intestine. Some dietary protein hydrolysates reportedly stimulate GLP-1 secretion in humans and animal models.

Acute intraduodenal infusion of whey protein hydrolysates $(3 \mathrm{kcal} / \mathrm{min}$ for $60 \mathrm{~min}$, total $180 \mathrm{kcal}=45 \mathrm{~g}$ ) increased plasma GLP-1 levels in healthy men [51], as well as in both lean and obese subjects [52]. Chronic ingestion of fish (blue whiting) protein hydrolysate (1.4 g/day), added to a meal for 90 days [53], increased plasma GLP-1 levels in marginally overweight subjects, whereas cod protein hydrolysate ingestion ( $\sim 40 \mathrm{mg} / \mathrm{kg}$ body weight/day) for 1 week did not affect GLP-1 levels in older adults [54].

Mechanisms underlying increased plasma GLP-1 levels in response to acute and chronic treatment with these factors are not necessarily common, as the former is a single stimulus-secretion coupling, but the latter includes adaptation to repeated stimulation. The adaptive mechanisms of dietary conditions in enteroendocrine cells remain largely elusive when compared with stimulus-secretion coupling mechanisms.

Oral administration of corn zein hydrolysate [55] and rice protein hydrolysate [56] stimulated GLP-1 secretion, which was accompanied by increased insulin secretion and decreased glycemia in rats, including diabetic Goto-Kakizaki rats [55]. Overall, dietary protein hydrolysates commonly stimulate GLP-1 secretion, although the relative potency varies among ingredients. Such variations are possibly caused by experimental conditions, including protein sources, enzymes used, duration, and combinations of digestive enzymes (such as pepsin, trypsin, chymotrypsin, pancreatin).

Owing to recent advances in peptidomic analysis using liquid chromatography with tandem mass spectrometry (LC-MS/MS), amino acid sequences of fragments in protein hydrolysates have been comprehensively decoded. Although limited in number and identifying very short peptides are technically challenging [57,58], peptide fragments with GLP-1 releasing activity have been identified, as shown in Table 1. Length of peptides vary from di- to undeca-peptide, and they do not seem to have any common structures or features. 
Selected tetrapeptides were identified to induce GLP-1 release from the human enteroendocrine cell line NCI-H716 [59]. A recent study demonstrated that a hydrophobic, positively charged peptide from egg white protein possesses potent GLP-1 releasing activity [60].

However, GLP-1-releasing peptides possibly possess specific features, as only limited but not all peptide fragments have the activity. Molecular mechanisms, especially the sensing mechanisms of dietary peptides in GLP-1-producing cells, have been partially clarified, as summarized in Figure 1.

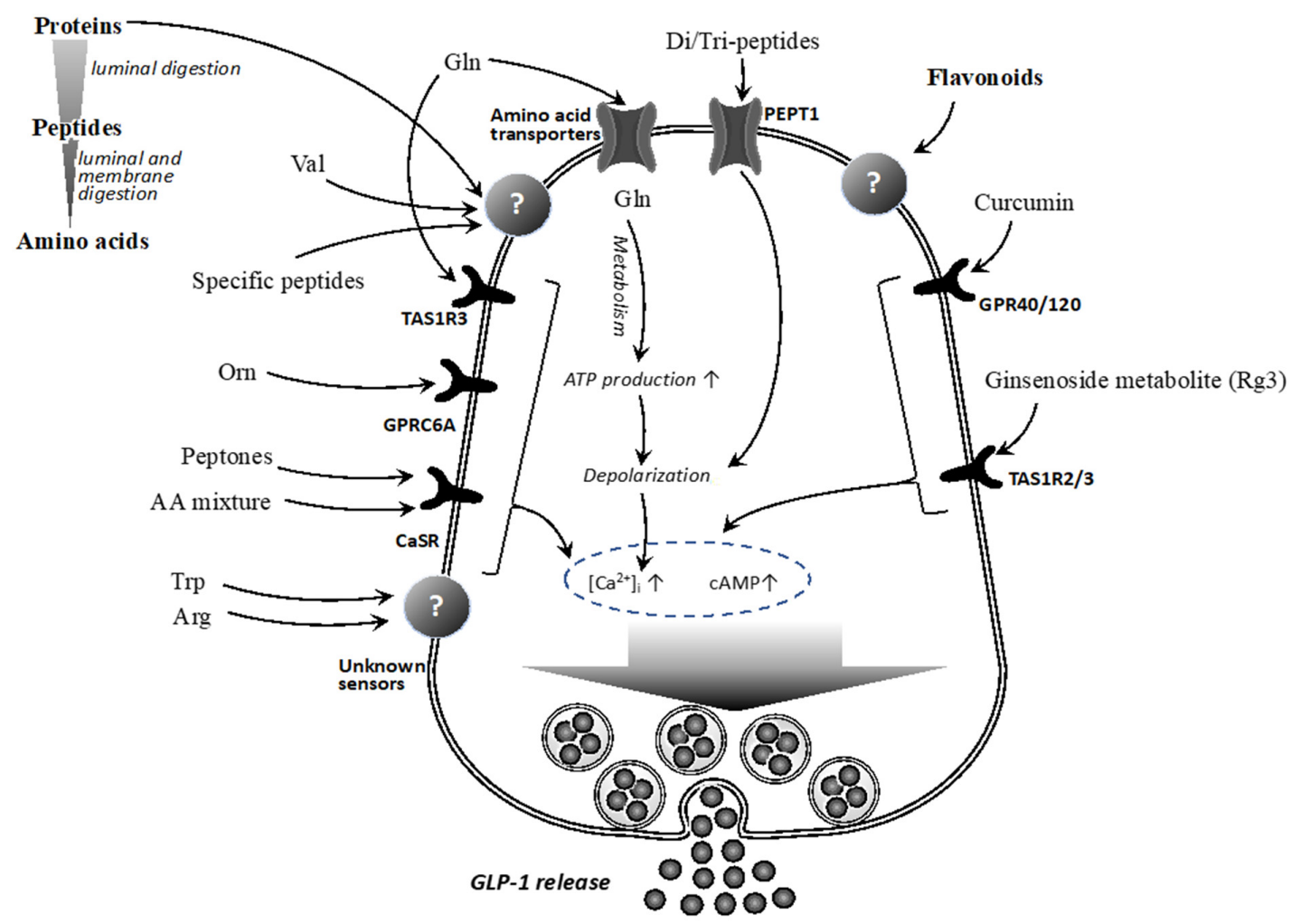

Figure 1. Sensing mechanisms of dietary proteins/peptides/amino acids and flavonoids in GLP-1-producing cells. Abbreviations; Gln, glutamine; Val, valine; Orn, ornithine; AA mixture, amino acids mixture; Trp, tryptophane; Arg, arginine; $\left[\mathrm{Ca}^{2+}\right]_{\mathrm{i}}$, intracellular calcium concentration; cAMP, cyclic adenosine mono-phosphate.

Peptide transporter-1 (PEPT1) is reportedly involved in GLP-1 secretion induced by glycylsarcosine (the non-hydrolyzable dipeptide PEP1 substrate) in L cells isolated from GLU-Venus transgenic mice, based on the cell-specific expression of the fluorescent protein Venus [33]. The involvement of CaSR has also been shown in peptone (an enzymatic meat hydrolysate)-induced GLP-1 secretion [33,34]; however, specific peptides have not been identified.

Numerous peptides are liberated from dietary proteins during luminal digestion in the stomach and small intestine. The degree of hydrolysis differs depending on the substrate, duration, amount of luminal enzymes, and intestinal region (duodenum, jejunum, ileum). The amount of luminal peptidases derived from the exocrine pancreas (trypsin, chymotrypsin, elastase, carboxypeptidases) is regulated by cholecystokinin (CCK), which is released from enteroendocrine I cells mainly located in the proximal small intestine, in response to nutrient ingestion, including fat and protein [61]. Therefore, it is challenging to mimic or estimate the components of luminal peptides in distinct intestinal regions.

Some active peptides might be released during the early period of luminal digestion in the proximal small intestine; however, they might be further digested and lose their activity before they reach the distal small intestine where GLP-1-producing cells are abundantly present. On the other hand, some small active peptides might be liberated after sufficient digestion in the small intestine, but they are immediately absorbed into epithelial cells 
before acting on GLP-1-producing cells. Despite these limitations, INFOGEST [62], a static in vitro simulation of gastrointestinal food digestion, helps identify and estimate peptide fragments after luminal digestion [60].

Although it has been postulated that luminal peptides act on CaSR located on the apical side of enteroendocrine cells to trigger GLP-1 secretion, a recent study using the isolated perfused proximal rat small intestine indicated that peptone-induced GLP-1 secretion depends on intestinal absorption and activation of basolaterally located CaSR [63]. Further investigations are needed to identify the active peptides and receptors involved in dietary protein hydrolysate-induced GLP-1 secretion.

In addition to stimulating GLP-1 secretion, dietary peptides are considered to enhance the survival of biologically active GLP-1 by reducing (inhibiting) DPP-4 activity in plasma. Sitagliptin, a non-peptidomimetic molecule, is an orally effective DPP-4 inhibitor that is widely employed as an incretin enhancer for the treatment of diabetes [7]. Although its potency is substantially lower than that of sitagliptin (IC50, $0.2 \mu \mathrm{M}$ ), some small peptides such as diprotin A (Ile-Pro-Ile) have been known to inhibit DPP-4 activity (IC50, $120 \mu \mathrm{M}$ ) [64]. Many small peptides derived from various dietary proteins demonstrate DPP-4 inhibitory activity, as observed in in vitro studies $[65,66]$. However, it remains unclear whether these peptides play a role in inhibiting plasma DPP-4 activity, followed by an increase in plasma GLP-1 levels in vivo.

The direct administration of corn zein hydrolysate [67] and rice protein hydrolysate [56] in anesthetized rats reduced plasma DPP-4 activity in the ileal mesenteric vein plasma. Furthermore, oral administration of whey protein stimulated GLP-1 secretion and afforded protection against GLP-1 degradation by DPP-4 in awake rats in experiments comparing GLP-1 responses to whey protein and dextrin with or without DPP-4 conditions [68]. This hypothesis is supported by similar experimental results observed in a previous mouse study [69], but it has not been evident in humans [70]. This could be attributed to the technical limitations of human studies, with only peripheral blood samples are available to assess DPP-4 activity. It can be postulated that the DPP-4 inhibitory and GLP-1-enhancing effects occur locally in the mesenteric blood. The GLP-1-releasing and GLP-1-enhancing effect of whey protein could be involved in its insulinotropic effect [71].

Table 1. Sequences and effective concentrations of dietary protein-based peptides and synthetic peptides that have GLP-1 releasing activity in various cellular models.

\begin{tabular}{|c|c|c|c|c|}
\hline $\begin{array}{l}\text { Peptide } \\
\text { Sequence }\end{array}$ & Models & $\begin{array}{l}\text { Concentration } \\
\text { Used (mM) }\end{array}$ & Source & Reference \\
\hline TKAVEH & STC-1 & 0.1 & bovine hemoglobin & Caron, J. Food Res Int 2016 [72] \\
\hline ANVST & STC-1 & 1 & bovine hemoglobin & Caron, J. Food Res Int 2016 [72] \\
\hline KAAVT & STC-1 & 1 & bovine hemoglobin & Caron, J. Food Res Int 2016 [72] \\
\hline YGAE & STC-1 & 1 & bovine hemoglobin & Caron, J. Food Res Int 2016 [72] \\
\hline GPVRGPFPIIV & GLUTag & 5 & $\beta$-casein & Komatsu, Y. Food Chem 2019 [50] \\
\hline PFL & STC-1 & 2 & egg white protein & Santos-Hernández, M. Food Chem 2020 [60] \\
\hline RVASMASEKM & STC-1 & 2 & egg white protein & Santos-Hernández, M. Food Chem 2020 [60] \\
\hline LKPT & STC-1 & 1 & tilapia byproduct & Theysgeur, S. Molecules 2020 [58] \\
\hline GGGG & NCl-H716 & 20 & synthetic & Le Nevé, B. Regul Pept 2011 [59] \\
\hline AAAA & NCl-H716 & 10 & synthetic & Le Nevé, B. Regul Pept 2011 [59] \\
\hline GWGG & NCl-H716 & 10 & synthetic & Le Nevé, B. Regul Pept 2011 [59] \\
\hline Glycylsarcosine & $\begin{array}{l}\text { Murine colon } \\
\text { primary culture }\end{array}$ & 10 & synthetic & Diakogiannaki, E. Diabetologia 2013 [33] \\
\hline LGG & $\begin{array}{l}\text { Murine colon } \\
\text { primary culture }\end{array}$ & 10 & synthetic & Diakogiannaki, E. Diabetologia 2013 [33] \\
\hline GF & $\begin{array}{l}\text { Murine colon } \\
\text { primary culture }\end{array}$ & 10 & synthetic & Diakogiannaki, E. Diabetologia 2013 [33] \\
\hline
\end{tabular}




\subsection{Amino Acids}

Not all amino acids stimulate GLP-1 secretion. Glutamine (Gln) was the first identified amino acid demonstrating potent GLP-1 releasing activity in murine GLUTag cells [73]. Subsequent studies revealed the involvement of elevated cytosolic calcium and cAMP in Gln-induced GLP-1 secretion in L cells [74]. Based on these studies, the involvement of a specific Gln receptor was suggested. One taste receptor subunit, TAS1R3, has been reported to be involved in Gln-induced GLP-1 secretion in GLUTag cells [75]. In contrast, another research group has suggested that Gln was transported into L cells and that the intracellular metabolism mediated by glutamate dehydrogenase (GDH) plays a role in Gln-induced GLP-1 secretion [76].

Ornithine (Orn) is a non-protein amino acid that potently stimulates GLP-1 secretion in GLUTag cells [77] and mice [78]. The involvement of a GPCR (GPRC6A) was demonstrated in GLUTag cells [77]; however, a study using GPRC6A knockout mice did not fully support this mechanism [78].

A recent study using the perfused proximal rat small intestine demonstrated that valine (Val) and Gln potently stimulated GLP-1 secretion only from the luminal side, but not from the vascular side, while arginine (Arg) and tryptophan (Trp) did only from the vascular side [79]. Accordingly, they concluded that amino acid-induced GLP-1 secretion involves both apical and basolateral (post-absorptive) sensing mechanisms. The apical sensing mechanism remains unknown, but the involvement of CaSR has been implicated in basolateral sensing mechanisms.

Human studies have revealed the stimulatory effect of orally administered Gln (30 g) on GLP-1 secretion in lean individuals, as well as in patients with obesity and type-2 diabetes [80], accompanied by a reduction in glycemia [81]. A clinical trial was conducted using a relatively lower dose of Gln $(6 \mathrm{~g})$ encapsulated with an enteric coating designed to promote capsule release $20 \mathrm{~min}$ after exposure to an alkaline environment [82]. Although a small increment of plasma GLP-1 was observed, it failed to exert beneficial metabolic effects on glucose tolerance and satiety. These results indicate that a $15-30 \mathrm{~g}$ dose of Gln is required to exert beneficial metabolic effects as a GLP-1 releaser in humans.

Considering the process of luminal digestion of dietary proteins, all factors derived from dietary proteins, including intact proteins, denatured proteins, partially digested peptides, oligopeptides, and free amino acids, can stimulate GLP-1 secretion depending on their structures and specific or unknown cellular mechanisms. Therefore, understanding protein/peptide/amino acid-induced GLP-1 secretion remains an attractive research target from a physiological perspective, as well as for the prevention and treatment of obesity and diabetes.

\section{Phytochemicals and GLP-1}

\subsection{Anti-Diabetic Effects of Phytochemicals, and Related Mechanisms}

Phytochemicals are naturally occurring compounds in plants that include a large number of chemical species. Extensive research in humans who consume phytochemical-rich foods and beverages has revealed a wide range of potential health benefits against diabetes and related diseases; however, sufficient data to recommend specific phytochemical intake are lacking [83-86]. Among the wide varieties of phytochemicals, flavonoids are the largest and most evaluated group [87]. Flavonoids are a class of low-molecular-weight phenolic compounds widely distributed in plants [88].

Notably, the anti-diabetic effects of flavonoids are partially attributed to their antioxidative properties and ability to modulate cellular signaling. Dietary genistein improved glucose tolerance and blood insulin levels in streptozotocin-induced diabetic mice, accompanied by improved islet beta-cell proliferation, survival, and mass. The beneficial effect on pancreatic beta-cells is mediated via activation of the cAMP/PKA-dependent ERK1/2 signaling pathway [89]. Both in vitro (INS-1 and MIN6 cell lines) and ex vivo (mouse pancreatic islets) models revealed that genistein directly exerted an insulinotropic effect through the cAMP/PKA signaling pathway in pancreatic beta-cells, independent of 
the estrogen receptor [90]. These beneficial effects of genistein have been demonstrated in postmenopausal women with type 2 diabetes mellitus [91]. However, the underlying mechanism has not been confirmed in human studies.

In a type 2 diabetic mouse model, quercetin ameliorated hyperglycemia and oxidative stress by lowering free radical-induced toxicity [92]. A co-formulation composed of quercetin and sitagliptin restored pancreatic islets and beta-cell function in diabetic rats [93]. (-)-Epicatechin reportedly exerts a beneficial effect on insulin sensitivity by downregulating oxidant production pathways that are known to inhibit insulin signaling [94]. Treatment with rutin reduced plasma glucose levels and attenuated oxidative stress and neuroinflammation via activation of the nuclear factor erythroid 2-related factor 2 (Nrf-2) pathway in the dorsal root ganglia of streptozotocin-induced diabetic rats [95]. Furthermore, several independent studies have demonstrated pancreatic beta-cell survival and/or pancreatic insulin release induced by phytochemicals such as fisetin [96], proanthocyanidin [97], and naringenin [98] in oxidative stress models.

Some flavonoids reportedly inhibit carbohydrate digestion, absorption, and metabolism. Tiliroside inhibited pancreatic $\alpha$-amylase in a dose-dependent manner and suppressed glucose uptake mediated by both SGLT1 and GLUT2 in the gastrointestinal tract [99]. Quercetin, epigallocatechin gallate (EGCG), and epicatechin gallate (ECG) inhibited the facilitative glucose transporter, GLUT1, by interacting at its exofacial sugar-binding site [100]. Naringenin [101], tangeretin [102], tricin [103], and quercetin [104] promoted glucose absorption in insulin-sensitive tissues via the translocation of GLUT4. Fisetin is another flavonoid that improved glucose homeostasis in streptozotocin-induced diabetic rats by inhibiting hepatic gluconeogenic enzymes (phosphoenolpyruvate carboxykinase and glucose6-phosphatase) [105]. In addition, rutin [106], kaempferol [107], and hesperidin [108] improved glucose tolerance by modifying carbohydrate metabolic enzymes.

\subsection{Phytochemicals and GLP-1}

As listed in Table 2, various flavonoids reportedly stimulate GLP-1 secretion in intestinal cell models and intestinal tissues and elevate plasma GLP-1 concentrations in animal models. As expected, most animal studies have shown improvements in glucose tolerance, along with increased plasma GLP-1 concentrations.

Using enteroendocrine cell models (murine GLUTag and human NCI-H716), stimulatory effects of curcumin [109], delphinidin 3-rutinoside [110], ginsenoside metabolite, Rg3 [111], hispidulin [112], and isoquercitrin [113] have been demonstrated. Although not well recognized, human Caco2 cells were employed to demonstrate GLP-1 secretion induced by EGCG [114]. Additionally, this study revealed the GLP-1 releasing activity of EGCG in a mouse intestinal tissue segment model.

Table 2. Flavonoids reported to elevate GLP-1 levels.

\begin{tabular}{|c|c|c|c|c|}
\hline Compound & Models & Treatment & Effect & Reference \\
\hline Apigenin & $\begin{array}{l}\text { High fat-high fructose } \\
\text { diet-fed rats }\end{array}$ & $\begin{array}{c}1.5 \mathrm{mg} / \mathrm{kg} \mathrm{BW}, \\
\text { intraperitoneal, } 30 \text { days }\end{array}$ & Plasma GLP-1个 & $\begin{array}{c}\text { Kalivarathan, J. J } \\
\text { Func Foods } 2020 \\
\text { [115] }\end{array}$ \\
\hline Curcumin & GLUTag cells & $10-50 \mu \mathrm{M}, 2 \mathrm{~h}$ & GLP-1 secretion $\uparrow$ & $\begin{array}{c}\text { Takikawa, M. } \\
\text { Biochem Biophys Res } \\
\text { Commun } 2013 \text { [109] }\end{array}$ \\
\hline Curcumin & Rats & $1.5 \mathrm{mg} / \mathrm{kg} \mathrm{BW}$, oral & $\begin{array}{c}\text { Plasma GLP-1 } \uparrow \\
\text { Glucose tolerance } \uparrow\end{array}$ & $\begin{array}{l}\text { Kato, M. Mol Nutr } \\
\text { Food Res } 2017 \text { [116] }\end{array}$ \\
\hline $\begin{array}{l}\text { Delphinidin } \\
\text { 3-rutinoside }\end{array}$ & GLUTag Cells & $10-100 \mu \mathrm{M}, 2 \mathrm{~h}$ & GLP-1 secretion $\uparrow$ & $\begin{array}{c}\text { Kato, M. PLoS One } \\
2015[110]\end{array}$ \\
\hline $\begin{array}{l}\text { Epigallocatechin-3- } \\
\text { gallate }\end{array}$ & $\begin{array}{c}\text { Caco-2 cells } \\
\text { Murine ileal tissue }\end{array}$ & $\begin{array}{c}300 \mu \mathrm{M}, 2 \mathrm{~h} \\
1 \mathrm{mM}, 45 \mathrm{~min}\end{array}$ & $\begin{array}{l}\text { GLP-1 secretion } \uparrow \\
\text { GLP-1 secretion } \uparrow\end{array}$ & $\begin{array}{c}\text { Song, WY. J Clin } \\
\text { Biochem Nutr } 2015 \\
\text { [114] }\end{array}$ \\
\hline
\end{tabular}


Table 2. Cont.

\begin{tabular}{|c|c|c|c|c|}
\hline Compound & Models & Treatment & Effect & Reference \\
\hline $\begin{array}{l}\text { Genistein } \\
\text { (combined with } \\
\text { metformin) }\end{array}$ & $\begin{array}{l}\text { Alloxan-induced diabetic } \\
\text { rats }\end{array}$ & $\begin{array}{l}20 \mathrm{mg} / \mathrm{kg} \mathrm{BW} / \text { day, } \\
\text { intraperitoneal, } 30 \text { days }\end{array}$ & $\begin{array}{l}\text { Serum and intestinal } \\
\text { GLP-1 } \uparrow \\
\text { Glucose tolerance } \uparrow\end{array}$ & $\begin{array}{c}\text { Rehman, K. Biomed } \\
\text { Pharmacother } 2019 \\
\text { [117] }\end{array}$ \\
\hline $\begin{array}{l}\text { Ginsenoside } \\
\text { metabolite, Rg3 }\end{array}$ & $\begin{array}{l}\text { NCI-H716 cells } \\
\mathrm{db} / \mathrm{db} \text { mice }\end{array}$ & $\begin{array}{c}1-25 \mu \mathrm{M}, 1 \mathrm{~h} \\
0.5 \mathrm{mg} / \mathrm{kg} \mathrm{BW}, \text { oral }\end{array}$ & $\begin{array}{c}\text { GLP-1 secretion } \uparrow \\
\text { Plasma GLP-1 } \uparrow \\
\text { Glucose tolerance } \uparrow\end{array}$ & $\begin{array}{l}\text { Kim, KS. Sci Rep. } \\
\text { 2015 [111] }\end{array}$ \\
\hline Hispidulin & $\begin{array}{l}\text { GLUTag cells } \\
\text { Mouse ileum crypts } \\
\text { STZ-treated mice }\end{array}$ & $\begin{array}{c}1-50 \mu \mathrm{M}, 1 \mathrm{~h} \\
1-50 \mu \mathrm{M}, 1 \mathrm{~h} \\
20 \mathrm{mg} / \mathrm{kg} \mathrm{BW} / \text { day, oral, } \\
6 \text { weeks }\end{array}$ & $\begin{array}{c}\text { GLP-1 secretion } \uparrow \\
\text { GLP-1 secretion } \uparrow \\
\text { Plasma GLP-1 } \uparrow \\
\text { Glucose tolerance } \uparrow\end{array}$ & $\begin{array}{l}\text { Wang, Y. Mol Nutr } \\
\text { Food Res } 2020 \text { [112] }\end{array}$ \\
\hline Isoquercitrin & $\begin{array}{c}\text { NCI-H716 cells } \\
\text { HFD-fed, STZ-treated } \\
\text { mice }\end{array}$ & $\begin{array}{l}10-100 \mu \mathrm{M}, 90 \mathrm{~min} \\
20-80 \mathrm{mg} / \mathrm{kgBW} / \text { day, } \\
\text { oral, } 8 \text { weeks }\end{array}$ & $\begin{array}{c}\text { GLP-1 secretion } \uparrow \\
\text { Plasma GLP-1 } \uparrow \\
\text { Plasma DPP-4 } \downarrow \\
\text { Plasma Glucose } \downarrow\end{array}$ & $\begin{array}{l}\text { Zang, L. RSC Adv } \\
2018[113]\end{array}$ \\
\hline Luteolin & HFD-fed mice & $\begin{array}{l}\text { Supplemented in diet, } \\
0.005 \%, 16 \text { weeks }\end{array}$ & $\begin{array}{c}\text { Plasma GLP-1 } \uparrow \\
\text { Glucose tolerance } \uparrow\end{array}$ & $\begin{array}{c}\text { Kwon, EY. Nutrients } \\
2018 \text { [118] }\end{array}$ \\
\hline Myricetin & $\begin{array}{c}\text { HFD-fed, STZ-treated } \\
\text { rats }\end{array}$ & $\begin{array}{c}20 \mathrm{mg} / \mathrm{kg} \mathrm{BW} / \text { day, oral, } \\
4 \text { weeks }\end{array}$ & $\begin{array}{c}\text { Plasma GLP-1个 } \\
\text { Plasma and tissue } \\
\text { DPP- } 4 \downarrow\end{array}$ & $\begin{array}{c}\text { Lalitha, N. PLoS One } \\
2020 \text { [119] }\end{array}$ \\
\hline $\begin{array}{l}\text { Proanthocyanidin } \\
\text { Gallic acid }\end{array}$ & Rat ileal segment & $\begin{array}{l}0.2 \mathrm{mg} / \mathrm{mL}, 1 \mathrm{~h} \\
31 \mu \mathrm{g} / \mathrm{mL}, 1 \mathrm{~h}\end{array}$ & $\begin{array}{l}\text { GLP-1 secretion } \uparrow \\
\text { GLP-1 secretion } \uparrow\end{array}$ & $\begin{array}{c}\text { Casanova-Martí, À. } \\
\text { Food Nutr Res } 2017 \\
{[120]}\end{array}$ \\
\hline Procyanidin & Cafeteria diet-fed rats & $\begin{array}{c}25 \mathrm{mg} / \mathrm{kg} \text { BW/day, oral, } \\
12 \text { weeks }\end{array}$ & Intestinal GLP-1个 & $\begin{array}{c}\text { González-Abuín, N. J } \\
\text { Agric Food Chem } \\
2014[121]\end{array}$ \\
\hline Resveratrol & HFD-fed mice & $\begin{array}{l}\text { Supplemented in diet, } 60 \\
\mathrm{mg} / \mathrm{kg} \mathrm{BW} / \text { day, } 5 \text { weeks }\end{array}$ & $\begin{array}{c}\text { Plasma GLP- } 1 \uparrow \\
\text { Glucose tolerance } \uparrow\end{array}$ & $\begin{array}{c}\text { Dao, TM. PLoS One } \\
2011 \text { [122] }\end{array}$ \\
\hline
\end{tabular}

Abbreviations: BW, body weight; DPP-4, dipeptidyl peptidase-4; GLP-1, glucagon-like peptide-1; HFD, high-fat diet; STZ, streptozotocin.

Interestingly, these compounds exert a stimulatory effect at relatively lower concentrations $(\mu \mathrm{M}$ or $\mu \mathrm{g} / \mathrm{mL})$ than dietary peptides and amino acids that require $\mathrm{mM}$ or $\mathrm{mg} / \mathrm{mL}$ concentration ranges, as described above (Table 1 ).

However, the molecular mechanisms (Figure 1) by which these flavonoids activate cells to release GLP-1 have not been comprehensively elucidated. To date, the involvement of free fatty acid receptors GPR40 and/or GPR120 in curcumin-induced GLP-1 secretion [116], and the sweet taste receptor in ginsenoside metabolite, Rg3-induced GLP-1 secretion [109], have been proposed.

In animal studies, GLP-1 secretion can be induced by acute (single) administration of curcumin [116], as well as the ginsenoside metabolite Rg3 [111]. Increment of plasma GLP-1 levels following chronic administration (oral or intraperitoneal) of apigenin [115], genistein combined with metformin [117], hispidulin [112], isoquercitrin [113], luteolin [118], myricetin [119], grape seed proanthocyanidins [120], procyanidin [121], and resveratrol [122] have been reported.

Some compounds (isoquercitrin and myricetin) reportedly possess inhibitory activity against the DPP-4 enzyme, which is considered to contribute to the promotive effect on GLP-1 levels $[113,119]$. Flavonoids mediate various protective effects against obesity, diabetes, and other metabolic diseases by targeting various organs, tissues, and cells, as described previously. Accordingly, the promotive effects of flavonoids on GLP-1 may, in part, mediate their health beneficial effects.

Most studies used purified flavonoids or flavonoid-enriched extracts. It is unlikely that humans have a sufficient amount of flavonoids from a single meal containing "flavonoidrich foods" for achieving the effective concentrations ( $\mu \mathrm{M}$ or $\mu \mathrm{g} / \mathrm{mL}$ range) in the intestinal lumen for stimulating GLP-1secretion. One previous human study demonstrated that the consumption of applesauce containing onion powder ( $\sim 100 \mathrm{mg}$ of quercetin aglycone equivalents) resulted in a maximum plasma quercetin concentration at $0.9 \mu \mathrm{M}$ [123]. Thus, 
in order to promote flavonoid-induced GLP-1 secretion, we would currently need to use purified- or concentrated flavonoids. However, continuous ingestion of flavonoid-rich foods may accumulate active flavonoids in the intestinal lumen or the blood circulation if the intestinal degradation of flavonoids was suppressed and the bioavailability of flavonoids was enhanced by coingestion of flavonoids with other food factors such as fermentable dietary fibers $[124,125]$.

\section{Concluding Remarks}

Lowering plasma glucose levels is considered a major target for treating or preventing glucose impairment, except when the possibility of hypoglycemia exists. Pharmaceutical approaches are potently effective but limited only to "patients" with a medical diagnosis. Nutraceutical approaches are not always efficacious but can be employed in subjects with pre-symptomatic status. Food factors targeting the liver, muscle, adipose tissues, and blood vessels need to be absorbed through the intestine and delivered to target cells via blood circulation.

Safety and bioavailability must be considered when such food factors are utilized in humans. However, when intestinal epithelial cells, including enteroendocrine cells, are targeted, especially when food factors act on the apical side, these factors do not need to cross the intestinal epithelium.

As reviewed above, GLP-1 secretion is stimulated by various food factors, indicating that, when needed, GLP-1 secretion can be increased by these food factors.

Thus, the utilization of low-digestible and/or low-absorbable materials, such as flavonoids and slowly digestible peptides, is a promising and safe strategy for the treatment and prevention of metabolic diseases, including obesity and glucose intolerance, by increasing GLP-1 secretion.

Funding: This research received no external funding.

Conflicts of Interest: The authors declare no conflict of interest.

\section{References}

1. Müller, T.; Finan, B.; Bloom, S.; D’Alessio, D.; Drucker, D.; Flatt, P.; Fritsche, A.; Gribble, F.; Grill, H.; Habener, J.; et al. Glucagon-like peptide 1 (GLP-1). Mol. Metab. 2019, 30, 72-130. [CrossRef]

2. Meier, J.J.; Nauck, M.A.; Kranz, D.; Holst, J.J.; Deacon, C.F.; Gaeckler, D.; Schmidt, W.E.; Gallwitz, B. Secretion, degradation, and elimination of glucagon-like peptide 1 and gastric inhibitory polypeptide in patients with chronic renal insufficiency and healthy control subjects. Diabetes 2004, 53, 654-662. [CrossRef]

3. Deacon, C.F. Physiology and Pharmacology of DPP-4 in Glucose Homeostasis and the Treatment of Type 2 Diabetes. Front. Endocrinol. 2019, 10, 80. [CrossRef]

4. Holst, J.J. The incretin system in healthy humans: The role of GIP and GLP-1. Metabolism 2019, 96, 46-55. [CrossRef]

5. Nauck, M.A.; Quast, D.R.; Wefers, J.; Meier, J.J. GLP-1 receptor agonists in the treatment of type 2 diabetes-state-of-the-art. Mol. Metab. 2021, 46, 101102. [CrossRef]

6. Buckley, S.T.; Bækdal, T.A.; Vegge, A.; Maarbjerg, S.J.; Pyke, C.; Ahnfelt-Rønne, J.; Madsen, K.G.; Schéele, S.G.; Alanentalo, T.; Kirk, R.K.; et al. Transcellular stomach absorption of a derivatized glucagon-like peptide-1 receptor agonist. Sci. Transl. Med. 2018, 10. [CrossRef]

7. Deacon, C.F. Dipeptidyl peptidase 4 inhibitors in the treatment of type 2 diabetes mellitus. Nat. Rev. Endocrinol. 2020, 16, 642-653. [CrossRef]

8. Toft-Nielsen, M.B.; Damholt, M.B.; Madsbad, S.; Hilsted, L.M.; Hughes, T.E.; Michelsen, B.K.; Holst, J.J. Determinants of the Impaired Secretion of Glucagon-Like Peptide-1 in Type 2 Diabetic Patients. J. Clin. Endocrinol. Metab. 2001, 86, 3717-3723. [CrossRef]

9. Muscelli, E.; Mari, A.; Casolaro, A.; Camastra, S.; Seghieri, G.; Gastaldelli, A.; Holst, J.J.; Ferrannini, E. Separate Impact of Obesity and Glucose Tolerance on the Incretin Effect in Normal Subjects and Type 2 Diabetic Patients. Diabetes 2007, 57, 1340-1348. [CrossRef]

10. Nauck, M.; Vardarli, I.; Deacon, C.F.; Holst, J.J.; Meier, J.J. Secretion of glucagon-like peptide-1 (GLP-1) in type 2 diabetes: What is up, what is down? Diabetologia 2011, 54, 10-18. [CrossRef]

11. Meier, J.J.; Nauck, M.A. Is secretion of glucagon-like peptide-1 reduced in type 2 diabetes mellitus? Nat. Clin. Pract. Endocrinol. Metab. 2008, 4, 606-607. [CrossRef]

12. Holst, J.J.; Knop, F.K.; Vilsbøll, T.; Krarup, T.; Madsbad, S. Loss of Incretin Effect Is a Specific, Important, and Early Characteristic of Type 2 Diabetes. Diabetes Care 2011, 34, S251-S257. [CrossRef] [PubMed] 
13. Calanna, S.; Christensen, M.; Holst, J.J.; Laferrère, B.; Gluud, L.L.; Vilsbøll, T.; Knop, F.K. Secretion of glucagon-like peptide-1 in patients with type 2 diabetes mellitus: Systematic review and meta-analyses of clinical studies. Diabetologia 2013, 56, 965-972. [CrossRef] [PubMed]

14. Faerch, K.; Torekov, S.; Vistisen, D.; Johansen, N.B.; Witte, D.R.; Jonsson, A.; Pedersen, O.; Hansen, T.; Lauritzen, T.; Sandbaek, A.; et al. GLP-1 Response to Oral Glucose Is Reduced in Prediabetes, Screen-Detected Type 2 Diabetes, and Obesity and Influenced by Sex: The ADDITION-PRO Study. Diabetes 2015, 64, 2513-2525. [CrossRef]

15. Hira, T.; Pinyo, J.; Hara, H. What Is GLP-1 Really Doing in Obesity? Trends Endocrinol. Metab. 2020, 31, 71-80. [CrossRef]

16. Nakajima, S.; Hira, T.; Hara, H. Postprandial glucagon-like peptide-1 secretion is increased during the progression of glucose intolerance and obesity in high-fat/high-sucrose diet-fed rats. Br. J. Nutr. 2015, 113, 1477-1488. [CrossRef] [PubMed]

17. Hira, T.; Suto, R.; Kishimoto, Y.; Kanahori, S.; Hara, H. Resistant maltodextrin or fructooligosaccharides promotes GLP-1 production in male rats fed a high-fat and high-sucrose diet, and partially reduces energy intake and adiposity. Eur. J. Nutr. 2017, 57, 965-979. [CrossRef] [PubMed]

18. Pinyo, J.; Hira, T.; Hara, H. Continuous feeding of a combined high-fat and high-sucrose diet, rather than an individual high-fat or high-sucrose diet, rapidly enhances the glucagon-like peptide-1 secretory response to meal ingestion in diet-induced obese rats. Nutrition 2019, 62, 122-130. [CrossRef]

19. Pinyo, J.; Hara, H.; Hira, T. Diet-induced obesity enhances postprandial glucagon-like peptide-1 secretion in Wistar rats, but not in diabetic Goto-Kakizaki rats. Br. J. Nutr. 2020, 1-13. [CrossRef] [PubMed]

20. Pinyo, J.; Hira, T.; Hara, H. Enhanced postprandial glucagon-like peptide-1 secretion during obesity development has a protective role against glucose intolerance induction in rats. Br. J. Nutr. 2019, 122, 411-422. [CrossRef] [PubMed]

21. Svendsen, B.; Pedersen, J.; Albrechtsen, N.J.W.; Hartmann, B.; Toräng, S.; Rehfeld, J.F.; Poulsen, S.S.; Holst, J.J. An Analysis of Cosecretion and Coexpression of Gut Hormones from Male Rat Proximal and Distal Small Intestine. Endocrinology 2015, 156, 847-857. [CrossRef]

22. Fothergill, L.J.; Furness, J.B. Diversity of enteroendocrine cells investigated at cellular and subcellular levels: The need for a new classification scheme. Histochem. Cell Biol. 2018, 150, 693-702. [CrossRef]

23. Reimann, F.; Gribble, F.M. Mechanisms underlying glucose-dependent insulinotropic polypeptide and glucagon-like peptide-1 secretion. J. Diabetes Investig. 2016, 7, 13-19. [CrossRef]

24. Kuhre, R.E.; Gribble, F.M.; Hartmann, B.; Reimann, F.; Windeløv, J.A.; Rehfeld, J.F.; Holst, J.J. Fructose stimulates GLP-1 but not GIP secretion in mice, rats, and humans. Am. J. Physiol. Gastrointest. Liver Physiol. 2014, 306, G622-G630. [CrossRef] [PubMed]

25. Jang, H.J.; Kokrashvili, Z.; Theodorakis, M.J.; Carlson, O.D.; Kim, B.-J.; Zhou, J.; Kim, H.H.; Xu, X.; Chan, S.L.; Juhaszova, M.; et al. Gut-expressed gustducin and taste receptors regulate secretion of glucagon-like peptide-1. Proc. Natl. Acad. Sci. USA 2007, 104, 15069-15074. [CrossRef]

26. Margolskee, R.F.; Dyer, J.; Kokrashvili, Z.; Salmon, K.S.H.; Ilegems, E.; Daly, K.; Maillet, E.; Ninomiya, Y.; Mosinger, B.; ShiraziBeechey, S.P. T1R3 and gustducin in gut sense sugars to regulate expression of $\mathrm{Na}^{+}$-glucose cotransporter 1. Proc. Natl. Acad. Sci. USA 2007, 104, 15075-15080. [CrossRef] [PubMed]

27. Steinert, R.E.; Gerspach, A.C.; Gutmann, H.; Asarian, L.; Drewe, J.; Beglinger, C. The functional involvement of gut-expressed sweet taste receptors in glucose-stimulated secretion of glucagon-like peptide-1 (GLP-1) and peptide YY (PYY). Clin. Nutr. 2011, 30, 524-532. [CrossRef]

28. Feltrin, K.L.; Little, T.J.; Meyer, J.H.; Horowitz, M.; Smout, A.J.P.M.; Wishart, J.; Pilichiewicz, A.N.; Rades, T.; Chapman, I.M.; Feinle-Bisset, C. Effects of intraduodenal fatty acids on appetite, antropyloroduodenal motility, and plasma CCK and GLP-1 in humans vary with their chain length. Am. J. Physiol. Regul. Integr. Comp. Physiol. 2004, 287, R524-R533. [CrossRef]

29. Thomsen, C.; Rasmussen, O.; Lousen, T.; Holst, J.J.; Fenselau, S.; Schrezenmeir, J.; Hermansen, K. Differential effects of saturated and monounsaturated fatty acids on postprandial lipemia and incretin responses in healthy subjects. Am. J. Clin. Nutr. 1999, 69, 1135-1143. [CrossRef]

30. Thomsen, C.; Storm, H.; Holst, J.J.; Hermansen, K. Differential effects of saturated and monounsaturated fats on postprandial lipemia and glucagon-like peptide 1 responses in patients with type 2 diabetes. Am. J. Clin. Nutr. 2003, 77, 605-611. [CrossRef]

31. Hansen, K.B.; Rosenkilde, M.M.; Knop, F.K.; Wellner, N.; Diep, T.A.; Rehfeld, J.F.; Andersen, U.B.; Holst, J.J.; Hansen, H.S. 2-Oleoyl Glycerol Is a GPR119 Agonist and Signals GLP-1 Release in Humans. J. Clin. Endocrinol. Metab. 2011, 96, E1409-E1417. [CrossRef]

32. Mandøe, M.J.; Hansen, K.B.; Hartmann, B.; Rehfeld, J.F.; Holst, J.J.; Hansen, H.S. The 2-monoacylglycerol moiety of dietary fat appears to be responsible for the fat-induced release of GLP-1 in humans. Am. J. Clin. Nutr. 2015, 102, 548-555. [CrossRef]

33. Diakogiannaki, E.; Pais, R.; Tolhurst, G.; Parker, H.E.; Horscroft, J.; Rauscher, B.; Zietek, T.; Daniel, H.; Gribble, F.M.; Reimann, F. Oligopeptides stimulate glucagon-like peptide-1 secretion in mice through proton-coupled uptake and the calcium-sensing receptor. Diabetologia 2013, 56, 2688-2696. [CrossRef]

34. Pais, R.; Gribble, F.M.; Reimann, F. Signalling pathways involved in the detection of peptones by murine small intestinal enteroendocrine L-cells. Peptides 2016, 77, 9-15. [CrossRef]

35. Mansour, A.; Hosseini, S.; Larijani, B.; Pajouhi, M.; Mohajeri-Tehrani, M.R. Nutrients related to GLP1 secretory responses. Nutrition 2013, 29, 813-820. [CrossRef]

36. Tolhurst, G.; Heffron, H.; Lam, Y.S.; Parker, H.E.; Habib, A.M.; Diakogiannaki, E.; Cameron, J.; Grosse, J.; Reimann, F.; Gribble, F.M. Short-Chain Fatty Acids Stimulate Glucagon-Like Peptide-1 Secretion via the G-Protein-Coupled Receptor FFAR2. Diabetes 2012, 61, 364-371. [CrossRef] 
37. Psichas, A.; Sleeth, M.L.; Murphy, K.; Brooks, L.; Bewick, G.; Hanyaloglu, A.C.; A Ghatei, M.; Bloom, S.R.; Frost, G. The short chain fatty acid propionate stimulates GLP-1 and PYY secretion via free fatty acid receptor 2 in rodents. Int. J. Obes. 2015, 39, 424-429. [CrossRef]

38. Christiansen, C.B.; Gabe, M.B.N.; Svendsen, B.; Dragsted, L.O.; Rosenkilde, M.M.; Holst, J.J. The impact of short-chain fatty acids on GLP-1 and PYY secretion from the isolated perfused rat colon. Am. J. Physiol. Gastrointest. Liver Physiol. 2018, 315, G53-G65. [CrossRef]

39. Hira, T.; Ikee, A.; Kishimoto, Y.; Kanahori, S.; Hara, H. Resistant maltodextrin promotes fasting glucagon-like peptide-1 secretion and production together with glucose tolerance in rats. Br. J. Nutr. 2015, 114, 34-42. [CrossRef]

40. Hayakawa, M.; Hira, T.; Nakamura, M.; Iida, T.; Kishimoto, Y.; Hara, H. Secretion of GLP-1 but not GIP is potently stimulated by luminal d-Allulose (d-Psicose) in rats. Biochem. Biophys. Res. Commun. 2018. [CrossRef]

41. Iwasaki, Y.; Sendo, M.; Dezaki, K.; Hira, T.; Sato, T.; Nakata, M.; Goswami, C.; Aoki, R.; Arai, T.; Kumari, P.; et al. GLP-1 release and vagal afferent activation mediate the beneficial metabolic and chronotherapeutic effects of D-allulose. Nat. Commun. 2018, 9, 113. [CrossRef]

42. Miguéns-Gómez, A.; Casanova-Martí, À.; Blay, M.T.; Terra, X.; Beltrán-Debón, R.; Rodríguez-Gallego, E.; Ardévol, A.; Pinent, M. Glucagon-like peptide-1 regulation by food proteins and protein hydrolysates. Nutr. Res. Rev. 2021, 1-17. [CrossRef]

43. Belza, A.; Ritz, C.; Sørensen, M.Q.; Holst, J.J.; Rehfeld, J.F.; Astrup, A. Contribution of gastroenteropancreatic appetite hormones to protein-induced satiety. Am. J. Clin. Nutr. 2013, 97, 980-989. [CrossRef]

44. Van Der Klaauw, A.A.; Keogh, J.M.; Henning, E.; Trowse, V.M.; Dhillo, W.; Ghatei, M.A.; Farooqi, I.S. High protein intake stimulates postprandial GLP1 and PYY release. Obesity 2013, 21, 1602-1607. [CrossRef]

45. Dougkas, A.; Östman, E. Protein-Enriched Liquid Preloads Varying in Macronutrient Content Modulate Appetite and AppetiteRegulating Hormones in Healthy Adults. J. Nutr. 2016, 146, 637-645. [CrossRef]

46. Ohlsson, L.; Alsalim, W.; Carr, R.D.; Tura, A.; Pacini, G.; Mari, A.; Ahrén, B. Glucose-lowering effect of the DPP-4 inhibitor sitagliptin after glucose and non-glucose macronutrient ingestion in non-diabetic subjects. Diabetes Obes. Metab. 2013, 15, 531-537. [CrossRef]

47. Geraedts, M.C.; Troost, F.J.; Fischer, M.A.; Edens, L.; Saris, W.H. Direct induction of CCK and GLP-1 release from murine endocrine cells by intact dietary proteins. Mol. Nutr. Food Res. 2010, 55, 476-484. [CrossRef] [PubMed]

48. Gillespie, A.L.; Calderwood, D.; Hobson, L.; Green, B.D. Whey proteins have beneficial effects on intestinal enteroendocrine cells stimulating cell growth and increasing the production and secretion of incretin hormones. Food Chem. 2015, 189, 120-128. [CrossRef]

49. Gillespie, A.L.; Green, B.D. The bioactive effects of casein proteins on enteroendocrine cell health, proliferation and incretin hormone secretion. Food Chem. 2016, 211, 148-159. [CrossRef] [PubMed]

50. Komatsu, Y.; Wada, Y.; Izumi, H.; Shimizu, T.; Takeda, Y.; Hira, T.; Hara, H. Casein materials show different digestion patterns using an In Vitro gastrointestinal model and different release of glucagon-like peptide-1 by enteroendocrine GLUTag cells. Food Chem. 2019, 277, 423-431. [CrossRef]

51. Ryan, A.T.; Feinle-Bisset, C.; Kallas, A.; Wishart, J.M.; Clifton, P.; Horowitz, M.; Luscombe-Marsh, N.D. Intraduodenal protein modulates antropyloroduodenal motility, hormone release, glycemia, appetite, and energy intake in lean men. Am. J. Clin. Nutr. 2012, 96, 474-482. [CrossRef] [PubMed]

52. Hutchison, A.T.; Feinle-Bisset, C.; Fitzgerald, P.C.; Standfield, S.; Horowitz, M.; Clifton, P.M.; Luscombe-Marsh, N.D. Comparative effects of intraduodenal whey protein hydrolysate on antropyloroduodenal motility, gut hormones, glycemia, appetite, and energy intake in lean and obese men. Am. J. Clin. Nutr. 2015, 102, 1323-1331. [CrossRef]

53. Nobile, V.; Duclous, E.; Michelotti, A.; Bizzaro, G.; Negro, M.; Soisson, F. Supplementation with a fish protein hydrolysate (Micromesistius poutassou): Effects on body weight, body composition, and CCK/GLP-1 secretion. Food Nutr. Res. 2016, 60, 29857. [CrossRef]

54. Jensen, C.; Dale, H.F.; Hausken, T.; Lied, E.; Hatlebakk, J.G.; Brønstad, I.; Lied, G.A.; Hoff, D.A.L. Supplementation with cod protein hydrolysate in older adults: A dose range cross-over study. J. Nutr. Sci. 2019, 8, e40. [CrossRef]

55. Higuchi, N.; Hira, T.; Yamada, N.; Hara, H. Oral Administration of Corn Zein Hydrolysate Stimulates GLP-1 and GIP Secretion and Improves Glucose Tolerance in Male Normal Rats and Goto-Kakizaki Rats. Endocrinology 2013, 154, 3089-3098. [CrossRef]

56. Ishikawa, Y.; Hira, T.; Inoue, D.; Harada, Y.; Hashimoto, H.; Fujii, M.; Kadowaki, M.; Hara, H. Rice protein hydrolysates stimulate GLP-1 secretion, reduce GLP-1 degradation, and lower the glycemic response in rats. Food Funct. 2015, 6, 2525-2534. [CrossRef]

57. De Cicco, M.; Mamone, G.; Di Stasio, L.; Ferranti, P.; Addeo, F.; Picariello, G. Hidden “Digestome”: Current Analytical Approaches Provide Incomplete Peptide Inventories of Food Digests. J. Agric. Food Chem. 2019, 67, 7775-7782. [CrossRef]

58. Theysgeur, S.; Cudennec, B.; Deracinois, B.; Perrin, C.; Guiller, I.; Lepoudère, A.; Flahaut, C.; Ravallec, R. New Bioactive Peptides Identified from a Tilapia Byproduct Hydrolysate Exerting Effects on DPP-IV Activity and Intestinal Hormones Regulation After Canine Gastrointestinal Simulated Digestion. Molecules 2020, 26, 136. [CrossRef]

59. Le Nevé, B.; Daniel, H. Selected tetrapeptides lead to a GLP-1 release from the human enteroendocrine cell line NCI-H716. Regul. Pept. 2011, 167, 14-20. [CrossRef]

60. Santos-Hernández, M.; Amigo, L.; Recio, I. Induction of CCK and GLP-1 release in enteroendocrine cells by egg white peptides generated during gastrointestinal digestion. Food Chem. 2020, 329, 127188. [CrossRef]

61. Chandra, R.; Liddle, R.A. Recent advances in pancreatic endocrine and exocrine secretion. Curr. Opin. Gastroenterol. 2011, 27, 439-443. [CrossRef] 
62. Brodkorb, A.; Egger, L.; Alminger, M.; Alvito, P.; Assunção, R.; Ballance, S.; Bohn, T.; Bourlieu-Lacanal, C.; Boutrou, R.; Carrière, F.; et al. INFOGEST static In Vitro simulation of gastrointestinal food digestion. Nat. Protoc. 2019, 14, 991-1014. [CrossRef]

63. Modvig, I.M.; Kuhre, R.E.; Holst, J.J. Peptone-mediated glucagon-like peptide-1 secretion depends on intestinal absorption and activation of basolaterally located Calcium-Sensing Receptors. Physiol. Rep. 2019, 7, e14056. [CrossRef]

64. Proença, C.; Freitas, M.; Ribeiro, D.; Tomé, S.M.; Araújo, A.N.; Silva, A.M.S.; Fernandes, P.A.; Fernandes, E. The dipeptidyl peptidase-4 inhibitory effect of flavonoids is hindered in protein rich environments. Food Funct. 2019, 10, 5718-5731. [CrossRef]

65. Nongonierma, A.B.; Fitzgerald, R.J. Features of dipeptidyl peptidase IV (DPP-IV) inhibitory peptides from dietary proteins. J. Food Biochem. 2017, 43, e12451. [CrossRef] [PubMed]

66. Patil, S.P.; Goswami, A.; Kalia, K.; Kate, A.S. Plant-Derived Bioactive Peptides: A Treatment to Cure Diabetes. Int. J. Pept. Res. Ther. 2020, 26, 955-968. [CrossRef]

67. Mochida, T.; Hira, T.; Hara, H. The Corn Protein, Zein Hydrolysate, Administered into the Ileum Attenuates Hyperglycemia via Its Dual Action on Glucagon-Like Peptide-1 Secretion and Dipeptidyl Peptidase-IV Activity in Rats. Endocrinology 2010, 151, 3095-3104. [CrossRef] [PubMed]

68. Shimizu, Y.; Hara, H.; Hira, T. Glucagon-like peptide-1 response to whey protein is less diminished by dipeptidyl peptidase-4 in comparison with responses to dextrin, a lipid and casein in rats. Br. J. Nutr. 2021, 125, 398-407. [CrossRef] [PubMed]

69. Gunnarsson, P.T.; Winzell, M.S.; Deacon, C.F.; Larsen, M.O.; Jelic, K.; Carr, R.D.; Ahrén, B. Glucose-Induced Incretin Hormone Release and Inactivation Are Differently Modulated by Oral Fat and Protein in Mice. Endocrinology 2006, 147, 3173-3180. [CrossRef] [PubMed]

70. Smith, K.; Davies, K.A.B.; Stevenson, E.J.; West, D.J. The Clinical Application of Mealtime Whey Protein for the Treatment of Postprandial Hyperglycaemia for People With Type 2 Diabetes: A Long Whey to Go. Front. Nutr. 2020, 7, 587843. [CrossRef] [PubMed]

71. Adams, R.L.; Broughton, K.S. Insulinotropic Effects of Whey: Mechanisms of Action, Recent Clinical Trials, and Clinical Applications. Ann. Nutr. Metab. 2016, 69, 56-63. [CrossRef] [PubMed]

72. Caron, J.; Cudennec, B.; Domenger, D.; Belguesmia, Y.; Flahaut, C.; Kouach, M.; Lesage, J.; Goossens, J.F.; Dhulster, P.; Ravallec, R. Simulated GI digestion of dietary protein: Release of new bioactive peptides involved in gut hormone secretion. Food Res. Int. 2016, 89, 382-390. [CrossRef]

73. Reimann, F.; Williams, L.; da Silva Xavier, G.D.S.; Rutter, G.; Gribble, F.M. Glutamine potently stimulates glucagon-like peptide-1 secretion from GLUTag cells. Diabetologia 2004, 47, 1592-1601. [CrossRef]

74. Tolhurst, G.; Zheng, Y.; Parker, H.E.; Habib, A.M.; Reimann, F.; Gribble, F.M. Glutamine Triggers and Potentiates Glucagon-Like Peptide-1 Secretion by Raising Cytosolic $\mathrm{Ca}^{2+}$ and cAMP. Endocrinology 2011, 152, 405-413. [CrossRef]

75. Nakamura, T.; Harada, K.; Kamiya, T.; Takizawa, M.; Küppers, J.; Nakajima, K.; Gütschow, M.; Kitaguchi, T.; Ohta, K.; Kato, T.; et al. Glutamine-induced signaling pathways via amino acid receptors in enteroendocrine L cell lines. J. Mol. Endocrinol. 2020, 64, 133-143. [CrossRef]

76. Andersson, L.E.; Shcherbina, L.; Al-Majdoub, M.; Vishnu, N.; Arroyo, C.B.B.; Carrara, J.A.; Wollheim, C.B.; Fex, M.; Mulder H.; Wierup, N.; et al. Glutamine-Elicited Secretion of Glucagon-Like Peptide 1 Is Governed by an Activated Glutamate Dehydrogenase. Diabetes 2017, 67, 372-384. [CrossRef]

77. Oya, M.; Kitaguchi, T.; Pais, R.; Reimann, F.; Gribble, F.; Tsuboi, T. The G Protein-coupled Receptor Family C Group 6 Subtype A (GPRC6A) Receptor Is Involved in Amino Acid-induced Glucagon-like Peptide-1 Secretion from GLUTag Cells. J. Biol. Chem. 2013, 288, 4513-4521. [CrossRef]

78. Clemmensen, C.; Jørgensen, C.V.; Smajilovic, S.; Bräuner-Osborne, H. Robust GLP-1 secretion by basic L-amino acids does not require the GPRC6A receptor. Diabetes Obes. Metab. 2017, 19, 599-603. [CrossRef]

79. Modvig, I.M.; Kuhre, R.E.; Jepsen, S.L.; Xu, S.F.S.; Engelstoft, M.S.; Egerod, K.L.; Schwartz, T.W.; Ørskov, C.; Rosenkilde, M.M.; Holst, J.J. Amino acids differ in their capacity to stimulate GLP-1 release from the perfused rat small intestine and stimulate secretion by different sensing mechanisms. Am. J. Physiol. Endocrinol. Metab. 2021. [CrossRef]

80. Greenfield, J.R.; Farooqi, I.S.; Keogh, J.M.; Henning, E.; Habib, A.M.; Blackwood, A.; Reimann, F.; Holst, J.J.; Gribble, F.M. Oral glutamine increases circulating glucagon-like peptide 1, glucagon, and insulin concentrations in lean, obese, and type 2 diabetic subjects. Am. J. Clin. Nutr. 2008, 89, 106-113. [CrossRef] [PubMed]

81. Samocha-Bonet, D.; Wong, O.; Synnott, E.-L.; Piyaratna, N.; Douglas, A.; Gribble, F.M.; Holst, J.J.; Chisholm, D.J.; Greenfield, J.R. Glutamine Reduces Postprandial Glycemia and Augments the Glucagon-Like Peptide-1 Response in Type 2 Diabetes Patients. J. Nutr. 2011, 141, 1233-1238. [CrossRef]

82. Meek, C.L.; Lewis, H.B.; Vergese, B.; Park, A.; Reimann, F.; Gribble, F. The effect of encapsulated glutamine on gut peptide secretion in human volunteers. Peptides 2016, 77, 38-46. [CrossRef] [PubMed]

83. Sotoudeh, G.; Abshirini, M.; Mahaki, B.; Bagheri, F.; Siassi, F.; Koohdani, F. Higher intake of phytochemical-rich foods is inversely related to prediabetes: A case-control study. Int. J. Prev. Med. 2018, 9, 64. [CrossRef]

84. Eslami, O.; Khoshgoo, M.; Shidfar, F. Dietary phytochemical index and overweight/obesity in children: A cross-sectional study. BMC Res. Notes 2020, 13, 1-5. [CrossRef] [PubMed]

85. Kim, M.; Park, K. Association between phytochemical index and metabolic syndrome. Nutr. Res. Pract. 2020, 14, 252-261. [CrossRef]

86. Mozaffarian, D. Dietary and policy priorities to reduce the global crises of obesity and diabetes. Nat. Food 2020, 1, 38-50. [CrossRef]

87. Hameed, A.; Galli, M.; Adamska-Patruno, E.; Krętowski, A.; Ciborowski, M. Select Polyphenol-Rich Berry Consumption to Defer or Deter Diabetes and Diabetes-Related Complications. Nutrients 2020, 12, 2538. [CrossRef] 
88. Panche, A.N.; Diwan, A.D.; Chandra, S.R. Flavonoids: An overview. J. Nutr. Sci. 2016, 5, e47. [CrossRef]

89. Fu, Z.; Zhang, W.; Zhen, W.; Lum, H.; Nadler, J.L.; Bassaganya-Riera, J.; Jia, Z.; Wang, Y.; Misra, H.; Liu, D. Genistein Induces Pancreatic $\beta$-Cell Proliferation through Activation of Multiple Signaling Pathways and Prevents Insulin-Deficient Diabetes in Mice. Endocrinology 2010, 151, 3026-3037. [CrossRef]

90. Liu, D.; Zhen, W.; Yang, Z.; Carter, J.D.; Si, H.; Reynolds, K.A. Genistein Acutely Stimulates Insulin Secretion in Pancreatic $\alpha$-Cells Through a cAMP-Dependent Protein Kinase Pathway. Diabetes 2006, 55, 1043-1050. [CrossRef]

91. Braxas, H.; Rafraf, M.; Hasanabad, S.K.; Jafarabadi, M.A. Effectiveness of Genistein Supplementation on Metabolic Factors and Antioxidant Status in Postmenopausal Women with Type 2 Diabetes Mellitus. Can. J. Diabetes. 2019, 43, 490-497. [CrossRef]

92. Alam, M.; Meerza, D.; Naseem, I. Protective effect of quercetin on hyperglycemia, oxidative stress and DNA damage in alloxan induced type 2 diabetic mice. Life Sci. 2014, 109, 8-14. [CrossRef]

93. Eitah, H.E.; Maklad, Y.A.; Abdelkader, N.F.; el Din, A.A.G.; Badawi, M.; Kenawy, S.A. Modulating impacts of quercetin/sitagliptin combination on streptozotocin-induced diabetes mellitus in rats. Toxicol. Appl. Pharmacol. 2019, 365, 30-40. [CrossRef]

94. Cremonini, E.; Fraga, C.G.; Oteiza, P.I. (-)-Epicatechin in the control of glucose homeostasis: Involvement of redox-regulated mechanisms. Free Radic. Biol. Med. 2019, 130, 478-488. [CrossRef]

95. Tian, R.; Yang, W.; Xue, Q.; Gao, L.; Huo, J.; Ren, D.; Chen, X. Rutin ameliorates diabetic neuropathy by lowering plasma glucose and decreasing oxidative stress via Nrf2 signaling pathway in rats. Eur. J. Pharmacol. 2016, 771, 84-92. [CrossRef]

96. Prasath, G.S.; Sundaram, S.; Subramanian, S.P. Fisetin averts oxidative stress in pancreatic tissues of streptozotocin-induced diabetic rats. Endocrine 2013, 44, 359-368. [CrossRef]

97. Bashir, N.; Manoharan, V.; Miltonprabu, S. Grape seed proanthocyanidins protects against cadmium induced oxidative pancreatitis in rats by attenuating oxidative stress, inflammation and apoptosis via Nrf-2/HO-1 signaling. J. Nutr. Biochem. 2016, 32, 128-141. [CrossRef] [PubMed]

98. Rajappa, R.; Sireesh, D.; Salai, M.B.; Ramkumar, K.M.; Sarvajayakesavulu, S.; Madhunapantula, S.V. Treatment With Naringenin Elevates the Activity of Transcription Factor Nrf2 to Protect Pancreatic $\beta$-Cells From Streptozotocin-Induced Diabetes In Vitro and In Vivo. Front. Pharmacol. 2019, 9, 1562. [CrossRef]

99. Goto, T.; Horita, M.; Nagai, H.; Nagatomo, A.; Nishida, N.; Matsuura, Y.; Nagaoka, S. Tiliroside, a glycosidic flavonoid, inhibits carbohydrate digestion and glucose absorption in the gastrointestinal tract. Mol. Nutr. Food Res. 2011, 56, 435-445. [CrossRef]

100. Ojelabi, O.A.; Lloyd, K.P.; De Zutter, J.K.; Carruthers, A. Red wine and green tea flavonoids are cis-allosteric activators and competitive inhibitors of glucose transporter 1 (GLUT1)-mediated sugar uptake. J. Biol. Chem. 2018, 293, 19823-19834. [CrossRef]

101. Zygmunt, K.; Faubert, B.; MacNeil, J.; Tsiani, E. Naringenin, a citrus flavonoid, increases muscle cell glucose uptake via AMPK. Biochem. Biophys. Res. Commun. 2010, 398, 178-183. [CrossRef]

102. Kim, M.S.; Hur, H.J.; Kwon, D.Y.; Hwang, J.-T. Tangeretin stimulates glucose uptake via regulation of AMPK signaling pathways in C2C12 myotubes and improves glucose tolerance in high-fat diet-induced obese mice. Mol. Cell. Endocrinol. 2012, 358, 127-134. [CrossRef] [PubMed]

103. Kim, S.; Go, G.-W.; Imm, J.-Y. Promotion of Glucose Uptake in C2C12 Myotubes by Cereal Flavone Tricin and Its Underlying Molecular Mechanism. J. Agric. Food Chem. 2017, 65, 3819-3826. [CrossRef] [PubMed]

104. Jiang, H.; Yamashita, Y.; Nakamura, A.; Croft, K.; Ashida, H. Quercetin and its metabolite isorhamnetin promote glucose uptake through different signalling pathways in myotubes. Sci. Rep. 2019, 9, 1-15. [CrossRef]

105. Prasath, G.S.; Pillai, S.I.; Subramanian, S.P. Fisetin improves glucose homeostasis through the inhibition of gluconeogenic enzymes in hepatic tissues of streptozotocin induced diabetic rats. Eur. J. Pharmacol. 2014, 740, 248-254. [CrossRef]

106. Prince, P.S.M.; Kamalakkannan, N. Rutin improves glucose homeostasis in streptozotocin diabetic tissues by altering glycolytic and gluconeogenic enzymes. J. Biochem. Mol. Toxicol. 2006, 20, 96-102. [CrossRef] [PubMed]

107. Alkhalidy, H.; Moore, W.; Wang, A.; Luo, J.; McMillan, R.P.; Wang, Y.; Zhen, W.; Hulver, M.W.; Liu, D. Kaempferol ameliorates hyperglycemia through suppressing hepatic gluconeogenesis and enhancing hepatic insulin sensitivity in diet-induced obese mice. J. Nutr. Biochem. 2018, 58, 90-101. [CrossRef]

108. Sundaram, R.; Nandhakumar, E.; Banu, H.H. Hesperidin, a citrus flavonoid ameliorates hyperglycemia by regulating key enzymes of carbohydrate metabolism in streptozotocin-induced diabetic rats. Toxicol. Mech. Methods 2019, 29, 644-653. [CrossRef]

109. Takikawa, M.; Kurimoto, Y.; Tsuda, T. Curcumin stimulates glucagon-like peptide-1 secretion in GLUTag cells via Ca2+/calmodulin-dependent kinase II activation. Biochem. Biophys. Res. Commun. 2013, 435, 165-170. [CrossRef]

110. Kato, M.; Tani, T.; Terahara, N.; Tsuda, T. The Anthocyanin Delphinidin 3-Rutinoside Stimulates Glucagon-Like Peptide-1 Secretion in Murine GLUTag Cell Line via the Ca2+/Calmodulin-Dependent Kinase II Pathway. PLoS ONE 2015, 10, e0126157. [CrossRef]

111. Kim, K.-S.; Yang, H.J.; Lee, I.-S.; Kim, K.-H.; Park, J.; Jeong, H.-S.; Kim, Y.; Ahn, K.S.; Na, Y.-C.; Jang, H.-J. The aglycone of ginsenoside $\mathrm{Rg} 3$ enables glucagon-like peptide-1 secretion in enteroendocrine cells and alleviates hyperglycemia in type 2 diabetic mice. Sci. Rep. 2015, 5, 18325. [CrossRef] [PubMed]

112. Wang, Y.; Wang, A.; AlKhalidy, H.; Luo, J.; Moomaw, E.; Neilson, A.P.; Liu, D. Flavone Hispidulin Stimulates Glucagon-Like Peptide-1 Secretion and Ameliorates Hyperglycemia in Streptozotocin-Induced Diabetic Mice. Mol. Nutr. Food Res. 2020, 64, e1900978. [CrossRef]

113. Zhang, L.; Zhang, S.-T.; Yin, Y.-C.; Xing, S.; Li, W.-N.; Fu, X.-Q. Hypoglycemic effect and mechanism of isoquercitrin as an inhibitor of dipeptidyl peptidase-4 in type 2 diabetic mice. RSC Adv. 2018, 8, 14967-14974. [CrossRef] 
114. Song, W.-Y.; Aihara, Y.; Hashimoto, T.; Kanazawa, K.; Mizuno, M. (-)-Epigallocatechin-3-gallate induces secretion of anorexigenic gut hormones. J. Clin. Biochem. Nutr. 2015, 57, 164-169. [CrossRef] [PubMed]

115. Kalivarathan, J.; Kalaivanan, K.; Chandrasekaran, S.P.; Nanda, D.; Ramachandran, V.; Venkatraman, A.C. Apigenin modulates hippocampal CREB-BDNF signaling in high fat, high fructose diet-fed rats. J. Funct. Foods 2020, 68, 103898. [CrossRef]

116. Kato, M.; Nishikawa, S.; Ikehata, A.; Dochi, K.; Tani, T.; Takahashi, T.; Imaizumi, A.; Tsuda, T. Curcumin improves glucose tolerance via stimulation of glucagon-like peptide-1 secretion. Mol. Nutr. Food Res. 2017, 61. [CrossRef]

117. Rehman, K.; Ali, M.B.; Akash, M.S.H. Genistein enhances the secretion of glucagon-like peptide-1 (GLP-1) via downregulation of inflammatory responses. Biomed. Pharmacother. 2019, 112, 108670. [CrossRef]

118. Kwon, E.-Y.; Choi, M.-S. Luteolin Targets the Toll-Like Receptor Signaling Pathway in Prevention of Hepatic and Adipocyte Fibrosis and Insulin Resistance in Diet-Induced Obese Mice. Nutrients 2018, 10. [CrossRef] [PubMed]

119. Lalitha, N.; Sadashivaiah, B.; Ramaprasad, T.R.; Singh, S.A. Anti-hyperglycemic activity of myricetin, through inhibition of DPP-4 and enhanced GLP-1 levels, is attenuated by co-ingestion with lectin-rich protein. PLoS ONE 2020, 15, e0231543. [CrossRef]

120. Casanova-Martí, À.; Serrano, J.; Blay, M.T.; Terra, X.; Ardévol, A.; Pinent, M. Acute selective bioactivity of grape seed proanthocyanidins on enteroendocrine secretions in the gastrointestinal tract. Food Nutr. Res. 2017, 61, 1321347. [CrossRef]

121. González-Abuín, N.; Martínez-Micaelo, N.; Blay, M.; Ardévol, A.; Pinent, M. Grape-Seed Procyanidins Prevent the Cafeteria-DietInduced Decrease of Glucagon-Like Peptide-1 Production. J. Agric. Food Chem. 2014, 62, 1066-1072. [CrossRef]

122. Dao, T.M.; Waget, A.; Klopp, P.; Serino, M.; Vachoux, C.; Pechere, L.; Drucker, D.J.; Champion, S.; Barthélemy, S.; Barra, Y.; et al Resveratrol Increases Glucose Induced GLP-1 Secretion in Mice: A Mechanism which Contributes to the Glycemic Control. PLoS ONE 2011, 6, e20700. [CrossRef]

123. Lee, J.E.; Mitchell, A.E. Pharmacokinetics of Quercetin Absorption from Apples and Onions in Healthy Humans. J. Agric. Food Chem. 2012, 60, 3874-3881. [CrossRef]

124. Trakooncharoenvit, A.; Tanaka, S.; Mizuta, E.; Hira, T.; Hara, H. Water-soluble dietary fibers enhance bioavailability of quercetin and a fiber derived from soybean is most effective after long-term feeding in rats. Eur. J. Nutr. 2020, 59, 1389-1398. [CrossRef]

125. Trakooncharoenvit, A.; Hara, H.; Hira, T. Combination of $\alpha$-Glycosyl-Isoquercitrin and Soybean Fiber Promotes Quercetin Bioavailability and Glucagon-like Peptide-1 Secretion and Improves Glucose Homeostasis in Rats Fed a High-Fat High-Sucrose Diet. J. Agric. Food Chem. 2021, 69, 5907-5916. [CrossRef] 